Fishers and Territorial Anxieties in China and Vietnam Narratives of the South China Sea Beyond the Frame of the Nation Roszko, Edyta

Published in:

Cross-Currents : East Asian History and Culture Review

DOI:

10.1353/ach.2017.0001

Publication date:

2017

Document version

Publisher's PDF, also known as Version of record

Document license:

CC BY-ND

Citation for published version (APA):

Roszko, E. (2017). Fishers and Territorial Anxieties in China and Vietnam: Narratives of the South China Sea Beyond the Frame of the Nation. Cross-Currents : East Asian History and Culture Review, 6(1), 20-51. [1]. https://doi.org/10.1353/ach.2017.0001 


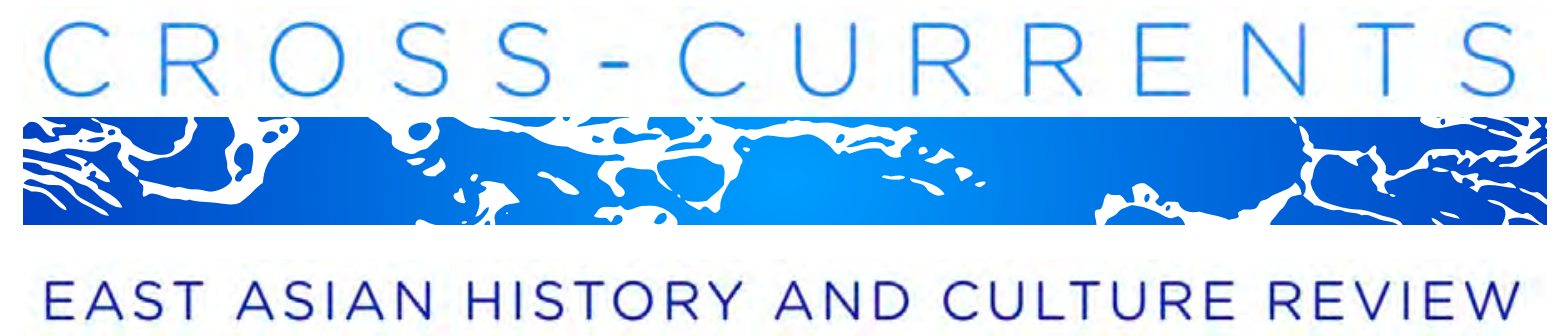

\title{
Fishers and Territorial Anxieties in China and Vietnam: Narratives of the South China Sea Beyond the Frame of the Nation
}

Edyta Roszko, University of Copenhagen

\begin{abstract}
In the geopolitical conflict over the South China Sea (SCS), fishers are at the center of Chinese and Vietnamese cartographic imaginations that define the sea as either "Chinese" or "Vietnamese" and hence tied to the disputed territories of the Paracel and Spratly Islands. While their historical presence and customary fishing rights in the SCS have been much publicized in the context of this territorial dispute, the long-standing Cham seafaring trade networks and legacy are ignored by both countries. The ethnic and national categories of Cham, Việt, and Han intersect with occupational categories such as those of fisher, trader, shipbuilder, sailor, and pirate, which in the past represented shifting, relational, and situational activities by the same people. The contemporary use of such professional and national labels produces particular political effects by projecting recent closures and enclosures onto the past, in spite of the common historical, cultural, and ethnic flows that always existed in the SCS. Rather than aiming to legitimize or delegitimize Vietnam's or China's territorial claims to the SCS, this article argues that seafaring narratives should be liberated from abstract, anachronistic discourses of sovereignty, territoriality, and territorial anxieties that separate the interconnected histories of the Cham, Vietnamese, and Chinese.
\end{abstract}

Keywords: Cham, Vietnamese, Chinese, fishing, nation-state, South China Sea, Paracel Islands, Spratly Islands

\section{Introduction}

By taking its jurisdictional claims to the United Nations Convention on the Law of the Sea Annex VII Arbitral Tribunal in 2013, the Philippines challenged China's demand that it not internationalize the issue of the South China Sea (SCS). On June 12, 2016, the definitive ruling issued by the Permanent Court of Arbitration (PCA) at The Hague made global headlines. The court not only refuted China's "nine-dash" claim" on the basis of historic rights, but it also stated that "although Chinese navigators and fishermen, as well as those of other states, had historically 
made use of the islands in the South China Sea, there was no evidence that China had historically exercised exclusive control over the waters or their resources."2 Opening a new legal chapter in the SCS disputes, the PCA decision was pathbreaking. It showed that none of the major claimants - China, Vietnam, or the Philippines - could claim 12 nautical miles of territorial sea or 200 nautical miles of an exclusive economic zone (EEZ) in the SCS due to historic fishing rights or land reclamation. The court's ruling not only offered insight into how historic fishing rights are used by states to enforce closures and enclosures at sea, but also goes to the heart of the cartographic imagination of China and of one of its most vocal opponents - Vietnam-as both states claim virtually all of the sea features in the Paracels and Spratlys.

In both China and Vietnam, the SCS disputes evoke strong nationalist feelings along with a desire to include far-distant waters and largely submerged reefs and shoals within a bounded national space. Chinese and Vietnamese historians, archaeologists, journalists, and citizens in their home countries and abroad have called for consolidated efforts to clarify facts, standardize understanding, and provide scientific and historical evidence of China's and Vietnam's "motherland" and of their "indisputable sovereignty" over the Paracel and Spratly archipelagos. ${ }^{3}$ In their claims to state sovereignty and treatment of the sea as land, China and Vietnam employ a rich arsenal of political strategies that help their citizens to imagine and identify with those remote reefs and rocks as part of their national territories (Roszko 2015). The "desire for mappability and the fear of unmappability (cartographic anxiety)" (Painter 2008, 349) animate man-made features, construction of artificial islands on the reefs, resettlement of fishers in disputed territories, state subsidies paid to fishers for their fishing operations in the Paracels and Spratlys, the establishment of the new Chinese administrative city of Sansha on the Paracels, and the practice of sending Vietnamese Buddhist monks to the Spratlys. ${ }^{4}$ Some of these strategies have been considered in terms of boundary delimitation, political development, and economic or military security (Bonnet 2012; Chemillier-Gendreau 2000; Tønnesson 2006; Hill, Owen, and Roberts 1991). However, seafaring narratives and fisheries as an object of analysis are rarely considered, despite being increasingly used for mapmaking and maritime territorialization (Roszko 2015).

In this article, I shift the gaze from the geopolitical conflict between China and Vietnam to fishing communities and long-term connections, flows, and networks in the SCS. Historically, ideological and cultural flows of knowledge, beliefs, expertise, technology, and goods - whether 
carried out by traders and seafarers on merchant ships or fishing junks - crossed vast ocean spaces and political boundaries, making the seas "unifying fields around which societies interacted" (Reid 1999, 39). For people living along the coast, the SCS always provided livelihoods from fishing, trade, and more: over centuries, different fishing communities, city ports, and urban markets formed multiple networks that linked up geographically distant coastal and maritime areas, straddling and transgressing borders without regard to the expansion of nation-states (Tagliacozzo 2009, 103).

With the early twentieth century's concept of homogeneous bounded space replacing imperial understandings of unbounded space and territory (Callahan 2009, 141, 146), fishers have been inscribed into a cartographic order of the present-day nation-state (Winichakul 1994; Hill 1991). The legal regime of the exclusive economic zone (EEZ) represents the largest enclosure in history, nationalizing vast expanses of ocean space and resources, and extending states' national sovereignty beyond the limits of terrestrial jurisdiction. Yet, in the context of the highly fluid material nature of the sea-whether in terms of migratory fish species or sea features that cannot sustain human life - sovereignty at sea remains an unsettled and extractive practice that states construct not in isolation but in relation to one another. The unboundedness of the sea and of seaborne networks and flows generates territorial anxiety predicated on a historically recent understanding of territoriality as a constituent of state-spatial thinking represented and produced through cartographic technologies (Elden 2009, 2013; Painter 2008). Consequently, the spatial and temporal connectedness existing at sea must be tamed and turned into the productive tool of a grid map representing contemporary closures and enclosure. The assertion of bounded, defined space takes effect in public discourses: the SCS has come to be seen as exclusively "Chinese" or "Vietnamese" waters where fishers and their customary practices are placed at the center of China's and Vietnam's cartographic imaginations and territorial claims.

In those rapidly changing and fluid zones, the territorial conflict over the two archipelagos put fishers in the vanguard of national sovereignty in the SCS, or "East Sea" (V. Biển Đông), and linked them to the goals of "economic growth, regime and national security" (Wirth 2016, 79; Roszko 2015). In addition, territorial claims encourage Vietnamese and Chinese fishers to redefine their mental maps and historical narratives of fishing territories in line with cartographic discourses projected by their respective states-a process often overlooked by international relations analyses of the SCS (see Buszynski and Roberts 2015). Unpacking fishers' 
narratives of historical connections with the disputed areas of the Paracels and Spratlys requires a deeper understanding of how ethnic classifications came to signify national ones, and how they are used together with occupational categories to draw maritime boundaries between Vietnam and China. My primary aim here is not merely to reiterate the well-worn argument that fishing and trade networks existed long before nation-states, but rather to show how the old circulations in maritime zones have been appropriated and transformed by state and non-state actors to serve contemporary geopolitical claims. To fully recognize these circulations and the territorial anxieties they produce, one needs to pay attention to both contemporary projections about fishers by their states and "long-term patterns of mobility developed from a historical ecology, driven... by coastal societies" (Wheeler 2015,34). Thus, I seek a broader perspective on the contemporary projection about fishers into the past, which overlays and conflates national and professional categories to serve the current narratives of the imagined sovereign territories of China and Vietnam.

Zooming in on coastal society and its mobility, I follow the trend among historians of underlining complex interrelationships and connections with regions themselves (Braudel 1995; Chaudhuri 1985; Hamashita 2008). While stressing maritime connections, networks, and transnational flows over vast oceans is not new, the political frame, administrative boundaries, and national histories still form the privileged units of historical analysis. In their seminal volume Asia Inside Out: Connected Places, anthropologist Helen Siu and historians Eric Tagliacozzo and Peter Perdue plead for attention to "the political ambiguities of these commercialized regions and the fluid cultural and political identities of those engaged with these places" $(2015,7)$. Maintaining the momentum of this plea (see Amrith 2013; Sheriff and Ho 2014; Hall 2011; Ho 2006; Li 1998; Tagliacozzo and Chang 2011; Tagliacozzo, Siu, and Perdue 2015; Tran and Reid 2006), I argue that narratives of fisheries in the SCS need to be liberated from abstract and anachronistic discourses of sovereignty, territoriality, and territorial anxieties that impose artificial boundaries in the form of monolithic ethnic categories and draw lines between littoral communities of Vietnam and China, despite their interconnected regional and occupational histories. Only then can we see the emerging "non-national actors, networks and movements" (Tran and Reid 2006, 4; see also Duara 1995; Krishna 1994; Sutherland 2014) spanning and transgressing diverse regions, islands, bays, and coasts across the SCS. 
This article is divided into three parts. The first section explores present-day seafaring narratives of Vietnam and China and current ways of imagining the SCS. The second section links this discussion to Cham seafaring narratives. The final section traces how the ethnic and national categories of Cham, Việt, and Han intersect and overlay professional categoriesincluding that of fisherman, trader, ship builder, sailor, and pirate - to produce an exclusive category of "Vietnamese" or "Chinese" fishers operating in the past. Interrogating these blurred categories, I conclude that such labels are used to produce particular political effects, in the form of recent enclosures of the SCS.

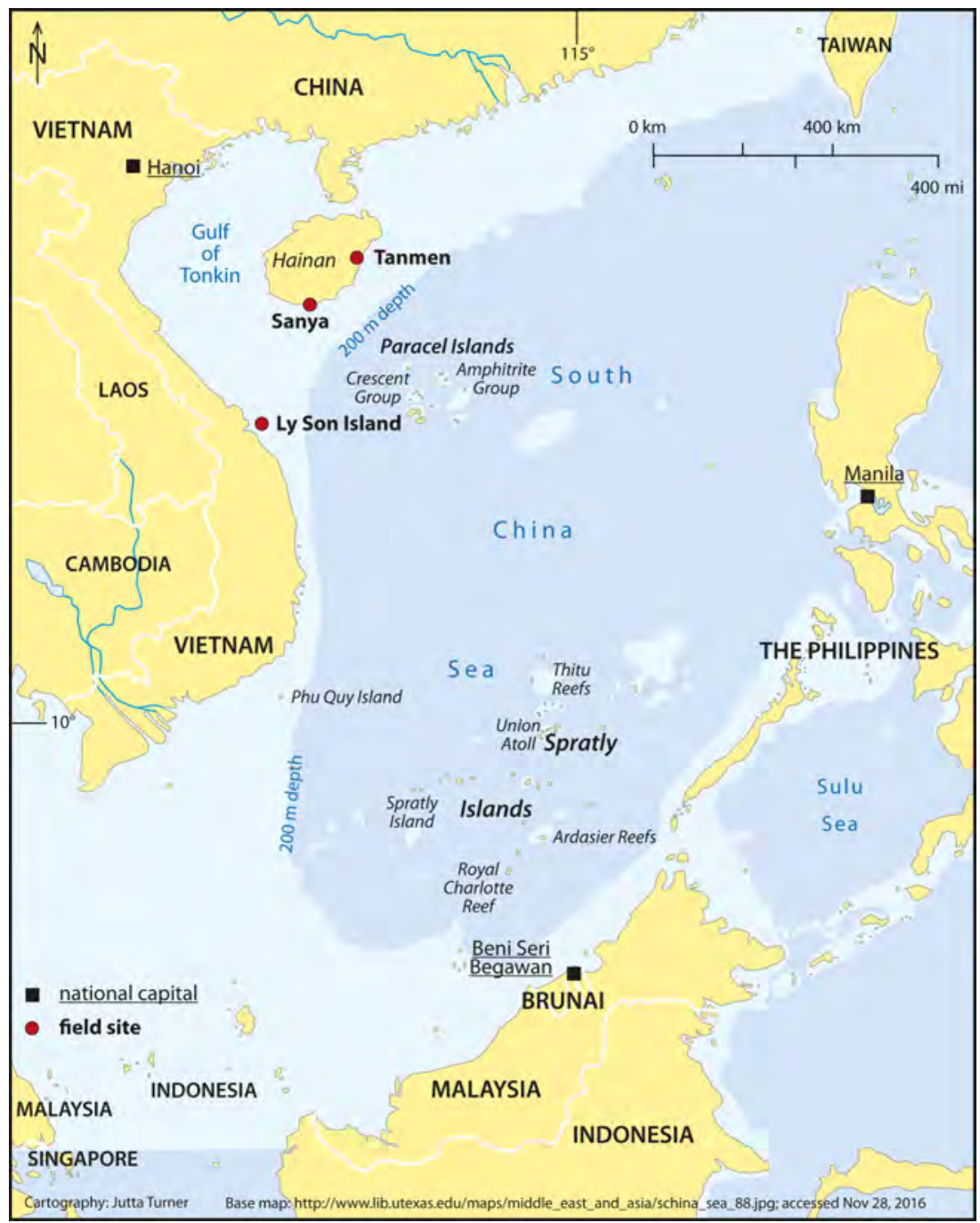

Map 1. The South China Sea: Lý Sơn Island in Vietnam and Tanmen and Sanya in China. Source: Base map available at http://www.lib.utexas.edu/maps/middle_east_and _asia/schina_sea_88.jpg; modified by Jutta Turner. 


\section{Connecting the South China Sea}

Two locations where centuries-old customary arrangements of fishers have become a medium through which Vietnam and China can visualize the sea as state territory are Vietnam's Lý Sơn Island and China's Hainan Island. Historically, the SCS was open sea for local fishers (see, for example, Gutzlaff 1849; Lê Quý Đôn [1776] 2006; Horsburgh 1852), but this has changed, as both Lý Sơn and Hainan are marked by their governments as border areas and stepping-stones to the Paracels and Spratlys. In the strategic locations of Lý Sơn and Hainan, states organize and recruit fishermen into maritime militias and designate areas for their fishing operations. In China, fishing activities are projected as an element of economic growth, "opening" (C. kaifa), "protecting" (baohu), and "developing the ocean economy" (fazhan haiyang jingji); in Vietnam, fisheries become a patriotic symbol of defending "territorial sovereignty" (V. bảo vệ chủ quyền lãnh thổ) over the Paracels and Spratlys. ${ }^{5}$

In April 2014, seven years after my initial doctoral fieldwork in 2006 and 2007, I returned to Lý Sơn Island for four months of fieldwork. Lý Sơn is a small atoll, formerly named Cù Lao Ré, which is the Vietnamese pronunciation of the Malay word Pulao, meaning island (see map 1). Located about 16 nautical miles (ca. $30 \mathrm{~km}$ ) offshore of Quảng Ngãi Province in Central Vietnam and 123 nautical miles (ca. $228 \mathrm{~km}$ ) from the Paracel archipelago, Lý Sơn became a "putative symbol of 'defending [Vietnam's] sovereignty' over the 'East Sea" (Roszko 2016, 348). China's repeated seizure of Lý Sơn fishing fleets and arrests of fishermen have been much publicized in the Vietnamese national media when relating the island's historical seafaring legacy. In March 2015, I conducted another four months of ethnographic research in a few coastal locations of Hainan Island, including the fishing town of Tanmen in Qionghai County and a Cham neighborhood in the city of Sanya (map 1). ${ }^{6}$ Tanmen fishermen are the best-known maritime militia. They have been directly involved in major conflicts in the SCS (Zhang 2016) and are considered by the Chinese government to continue the "ancient tradition of cultivating the sea." Less well known is the Cham community in Sanya and its historic connections with the SCS. While the seafaring legacy of Lý Sơn and Tanmen have gained much publicity in recent years, the Cham historical presence at sea is disregarded by both Vietnam and China - a point to which I will return later.

Having the rare opportunity to spend time on both the Vietnamese and Chinese sides of the maritime border, I started my ethnographic immersion by looking more closely at how 
fishers position themselves in the context of the recent geopolitical dispute and often informal marine trade between Vietnam and China. When asked directly whether they have any knowledge of the other or memory of their encounters at sea, Tanmen and Lý Sơn fishers usually denied that the "other side" was ever present in the Paracels or Spratlys. Yet, when asked indirectly about their seafaring experience, they would recall stories of their fathers and grandfathers running each other at sea and describe other encounters with dark-skinned seafarers wearing plain scarves around their heads (probably Cham or Malay sailors who were present there as well). ${ }^{7}$

Both groups, however, conveyed deep territorial anxiety over "the space of [national] desire" (Krishna 1994, 510) that is now the SCS. In China, the central and local state provides subsidies to Tanmen fishers, whose maritime operations stretch China's borders across the Paracels and Spratlys; in Vietnam, Vietnamese citizens, rather than the government, donate money to encourage fishers to cling to the sea and their fishing grounds to defend national sovereignty (V. bám ngu truờng để bảo vệ chủ quyền tổ quốc) (Roszko 2016, 369). The economic incentives extended to Chinese fishers and the narratives about Vietnamese fishers allegedly victimized by Chinese vessels produce not only asymmetric relations between the two countries and fishing groups, but also different anxieties that are manifested, calmed, and translated into desires and hopes (Broers and Toal 2013; Krishna 1994; Painter 2008). As a result, these anxieties function like a mirror, distorting old fishing arrangements by making them mutually exclusive to fit a narrow image of national territorial claims.

\section{Navigating the South China Sea}

Recently, China has been replacing traditional wooden fishing vessels with steel-hulled trawlers equipped with high-tech navigational and communication systems. These boats are believed to extend the imagined national geo-body-composed of both territory and nation (Winichakul 1994) - to cover stretches of the SCS. However, until the mid-1980s, the mobility of fishers in Tanmen and Lý Sơn was severely restricted by the states. While Tanmen fishers often relied on maps obtained during earlier sea voyages to Singapore, in Lý Sơn, fishers used simple administration maps stolen from the local People's Committee office when commencing their daring journeys to the Paracels and Spratlys at the beginning of the 1980s. At the time, when navigation and nautical charts were not available, Tanmen fishers relied on local 
navigational knowledge passed from father to son, sometimes in the form of a "logbook." In those family logbooks men recorded time, distance, currents, tides, the position of stars, passing birds, and many other details observed during their sea voyages. In traditional navigation, geng was an important term used to measure distance by many Hainanese sailors. One geng is equivalent to 60 Chinese miles ( $(i)$, but one full day from morning to midnight would be equal to approximately 10 geng. As Tanmen fishers explained, they used the "geng method" together with a few lighted incense sticks to calculate the time and direction of their passage on the sea. Since sailing to the Paracels required their boats to move on a zigzag course to avoid hidden rocks, the sailors followed the information in their logbooks and their own experience to calculate how many incense sticks had to be burned before each turn. Today, these logbooks, known in China as Geng lu bu (Manual of sea routes), are used by the Chinese government as evidence of a long-standing Chinese presence in the disputed archipelagos and "ironclad proof of China's sovereignty over the South China Sea," even though the traditional navigational knowledge was not unique to Tanmen fishers. ${ }^{8}$ Lý Sơn sailors also kept records of their voyages to the Paracels and Spratlys and measured distance with incense sticks, as did Tanmen and many fishers in the region, before nautical charts came into widespread use.

Most of the time, however, fishers tried to convince me that Chinese or Vietnamese, depending on which group they came from, were the "only group" to have, since "time immemorial," the intimate knowledge needed to reach their "ancestral waters." For example, when I asked Lý Son villagers about the presence of Hainan fishers in the area of the two archipelagos, one fisherman quickly shook his head and replied:

According to the ancient historical books, from the period of the Nguyễn Lords [1558-1777] until the King Gia Long [1762-1820], the Paracels (V. Hoàng Sa) and Spratlys (V. Trường Sa) belonged to Vietnam. As for China at that time, Chinese from Hainan Island could only go down up to 12 nautical miles, certainly could not go down to the Paracels, because the Paracels belonged to Vietnam. Hainan people did not have such favorable wind to go to the Paracels as Lý Sơn people had. They only fished close to Hainan or in the Tonkin Gulf.

One Tanmen resident was equally ungenerous in his opinion:

If Vietnamese people go to the Paracels (C. Xisha) or the Spratlys (C. Nansha), they learned [how to do so] from Tanmen people. In the past they did not have any boats; they had just bamboo basket-boats (C. luo kuan; V. ghe bầu). 
Note that the Lý Sơn fisherman referred to territorial waters as defined by the 1982 United Nations Convention of the Law of the Sea (UNCLOS), which extended a belt of coastal waters up to 12 nautical miles. ${ }^{9}$ He projected a current legal concept into the past to explain why Hainan sailors could not go to the Paracels. He also claimed an advantage over Hainan as a result of Lý Sơn's geographical location. In turn, the Tanmen villager disparaged the maritime knowledge and navigation skills of Vietnamese fishers by pointing to the technological inferiority of their boats compared to Tanmen boats.

But one needs to be careful about taking these pejorative remarks as absolute and as defining the relationship between Chinese and Vietnamese fishers. Referring to their more recent interactions (C. jiao liu; V. giao luu) at sea, Tanmen and Lý Sơn men told me in detail that they used sign language to communicate with one another; exchanged cigarettes, food, fuel, and water; and helped one another in times of disaster. Young Tanmen fishermen proudly showed off their knowledge of a few Vietnamese words that they had learned when Vietnamese fishermen invited them on board to share a meal and a glass of rice liquor. They repeated a Vietnamese invitation to eat-ăn com! (literally, "Eat rice!")——back to me, exactly as learned from their Vietnamese hosts. Another example of how Chinese and Vietnamese fishers perceive each other comes from a Tanmen woman who stayed in the Paracels for over a year to be closer to her husband, whose trawler operated between the disputed archipelagos for more than two months at a stretch. She told me that she often saw Vietnamese fishing boats anchored in the vicinity of the Paracels, their crews busily collecting sea cucumbers. She said, "They are fishers like we are, and they need to earn their living too, so we do not disturb each other." Her statement made more sense to me when I learned that the sea cucumbers collected by the Vietnamese often end up in Tanmen's traditional marine pharmaceuticals. The sea not only divides but, more importantly, connects the Tanmen and Lý Sơn fisheries through the collection of and trade in many marine products used for tourist souvenirs, jewelry and decoration, and traditional medicine. Unseen by customs, endangered species are directly transferred from Vietnamese to Chinese fishing vessels at sea or transported by Sino-Vietnamese traders to Guangxi or Guangdong Province. The collection and trade in these goods might take place on a relatively small scale, but they nevertheless link the Chinese and Vietnamese economies, as the economic value of "rare" and "exotic" marine products increases along with demand in a situation of ecological deterioration. 
These ethnographic examples reveal different patterns of Vietnamese-Chinese interaction and people's "micro-strategies" (Chan 2013, 123) for navigating the sea border. Political scientist Hongzhou Zhang $(2016,69)$ observes that, although the 2014 Sino-Vietnamese 981 oil rig row involved both Chinese and Vietnamese fishing boats, many Tanmen fishermen refused the Chinese government's request that they defend the oil rig installed in Vietnam's exclusive economic zone. ${ }^{10}$ Similarly, the head of the Tanmen fishing organization-whom I interviewed in March 2015 - said that Vietnamese and Chinese fishers had friendly relations and that if violent clashes happened they usually involved "army people." In her studies on VietnameseChinese relations in the borderlands, anthropologist Yuk Wah Chan $(2013,123)$ made clear that people living on the margins need to be pragmatic in seeking their livelihood, while those "in the center fight for the ideology of sovereignty and national pride." Territorial anxieties are part of this process, but they also express a whole spectrum of fears connected with both making a living and the desired image of the national territory.

\section{The Cham Seafaring Narratives}

Between 1993 and 1994, under the direction of the late prime minister Võ Văn Kiệt, Vietnamese archaeologists carried out excavations on the Spratly archipelago, including in the islets of Namyit (V. Đảo Nam Yết), Sin Cowe (V. Đảo Sơn Cả), and Sand Cay (V. Đảo Sinh Tổn). The artifacts, mainly ceramic, that they discovered were dated to the Early Iron Age. This would hardly be considered an archeological revelation were it not for the recent increase in scientific and official interest in the SCS, in which all historical and cultural relics are potentially useful. In search of the national past of the SCS, Vietnamese archaeologist Lại Văn Tới ascribed the artifacts from the Spratlys to the Sa Huỳnh culture - a distinct Bronze Age culture of Austronesian seafarers who flourished in central and southern Vietnam between 1000 B.C. and 200 A.D. - as "the very priceless materials to prove Vietnam sovereignty and territorial waters" $(2015,70)$. Furthermore, Lại Văn Tới classified the articles as "early Champa culture," affirming "that about 2,000 to 2,500 years ago, ancient Vietnamese people already conquered, inhabited, possessed and exploited [Spratly] archipelagos inside Vietnam's territorial waters in [the] East Sea" (2015, 53). Considering that only in the seventeenth century did Champa and its Austronesian-speaking inhabitants became part of the Việt polity through gradual southward expansion and colonization, such use of archeology is a good example of how, by extension of 
national time and space, "Vietnamese identity" is projected far into the past and onto people who were not part of the contemporary nation-state.

In early Southeast Asia, the Cham were known not only as skillful seafarers and successful merchants but also as "pirates" (Hall 2011), due to their naval raids on coastal areas. Between the seventh and fifteenth centuries they established their rule over coastal plains and mountain zones in what is now south-central Vietnam. The Cham never formed a unified kingdom, and their naval attacks on the coast drew on ethnically diverse maritime people (Hall 2011, 80). In the fifteenth century, Champa was invaded by Đại Việt—the name of the Việt polity at the time - which gradually took control of the entire Cham territory; only in the sixteenth and seventeenth centuries were the Nguyễn lords able to establish their power in the South. The civil war of the Nguyễn with the Trịnh lords (1627-1672 and 1774-1775), which divided Vietnam into northern and southern realms, created conditions for Việt migrants living in the new land to form their own distinct way of life. Central Vietnam was part of the southern realm and provided an option for northern Vietnamese migrants who, driven by lack of land, famine, internal conflict, and struggles for power, were seeking a better life elsewhere. Asia historian Tana Li (1998) points out that the Việt who arrived in the seventeenth century had to settle in a different environment and engage with Cham communities. Their gradual extension into new areas in the South led migrants to escape domination by the northern court in the Red River Delta, and to adopt local elements like Cham deities or spirit cults, which were free from Confucian restrictions ( $\mathrm{Li}$ 1998, 101-116). Vietnamese migrants colonizing the old Cham territory worshiped tutelary spirits that they had never worshiped in their places of origin. The new experience of the sea, the encounter with the unfamiliar Cham civilization, and interethnic marriages produced quite different patterns from those of northern Vietnam (Li 1998).

Therefore, casting light on regional narratives of the SCS within present-day Vietnam and China requires a closer look at the seafaring experience of Vietnamese, Cham, and Chinese, who must not be viewed as discrete groups (Wheeler 2006). The unique navigation skills of Lý Son sailors capitalized precisely on seafaring techniques of their Cham predecessors. Prior to the Việt arrival on Lý Sơn in the seventeenth century, the island was part of the Cham network of ports and trading systems in the SCS that connected the Middle East with Africa and China (see Reid 1999, 43). ${ }^{11}$ The Cham trading networks also included Hainan Island and Guangzhou, where Cham merchant communities have existed for over a thousand years (Thurgood 1999, 227), 
interacting and engaging in commerce with Chinese as well as Arab, Persian, Jewish, and Indian merchants, many of whom formed settlements in southern China.

When I visited one of the two Cham neighborhoods located outside Sanya city, I encountered people who clearly pointed out that their ancestors came from Vietnam and believed that they speak the same language as their Cham fellows in Vietnam. When asked why their ancestors left Vietnam, some said that they had been caught in storms at sea and could not find their way back. Others, appearing uneasy, lowered their voices and gave the war with the Việt and their inability to defend themselves as reasons for their migration. An eighty-three-year-old Cham man (b. 1933) asked why, if the typhoon had been a genuine reason for their arrival in Hainan, the Cham wanted to stay on the island instead of returning to Vietnam? He gave the following account of this bitter experience:

One thousand years ago, consumed by flames of fire and covered with clouds of smoke, the Việt (Yuenan) territory was plunged into the chaos of war. The cities were swept by death, political affairs were paralyzed, and [Cham] lives hardened as their property was taken away. When in those oppressive years their faith started to fade they left [Vietnam] without hope of returning. Women, old men, and children took a long and difficult path,... driven aimlessly by the sea into the far corners of the earth....

Those wandering Muslims arrived in a mysterious, depopulated, and backward place where the environment was harsh.... They arrived at the Asian coastline that had a huge bay on the west side of Plum Mountains (Sanya). Exploring the sea and its paths and depth many times they finally settled down, built up their fortune, established business and maintained their livelihoods....

Taking roots in this deserted and wild territory, Huizu [Chinese Muslims] were born from the wind and rain and from the sweat as they worked at sea.... Generation after generation, dynasty after dynasty, they sacrificed themselves and endured heavy and difficult social transformations. They are the family that was broken up and its members dispersed. Put to the severe test, after all that, they did not surround and assimilate or allow themselves to be fear-stricken, because their [Muslim] identity is in their blood and sustains their fight to improve their lives.

According to linguists Graham Thurgood, Ela Thurgood, and Li Fengxiang (2006, 20), Sanya functioned as a port on the Cham trade route between southern China and Annam (central Vietnam) until the fall of Vijaya in the fifteenth century. This suggests that the Cham refugees must have been aware of Sanya before making it their new home. However, the old man later said that Sanya was not the only entry point to the trading route and that different groups of Cham refugees had entered Hainan at several other points on the coast, including Wanning, 
Danzhou, and Lingshui. While today the Cham occupy only two neighborhoods, in the past their settlements were scattered widely along the Hainan shore (Thurgood, Thurgood, and Li 2006, 24). Like other fishing groups in southern China or in Vietnam, they were landless and buried their dead on the beach, a practice that has survived among Hainan Cham until the present day. While stressing their Muslim tradition and Vietnam as a place of their ancestors' origin, some Cham in Sanya confessed their Chinese, Arab, and Malay heritage. They also openly stated that some of their ancestors who settled in Danzhou, Wanning, or Lingshui intermingled with local populations and gradually became Han.

Thurgood, Thurgood, and Li $(2006,24)$ note that fishing and trade were always the main economic bases of the Cham in Hainan. They refer to a tablet from 1753, which was deciphered by a Chinese scholar in front of the mosque in Sanya in 1981. The tablet recorded the Yazhou government's decision in a legal dispute over control of sea fishing grounds - apparently in favor of the Cham (Thurgood, Thurgood, and Li 2006, 24). The Cham elder confirmed that, indeed, trade and fishing were important activities for centuries, but he also explained that this changed after the Japanese invasion of Hainan (1939-1945), when Cham homes, mosques, fishing equipment, and boats were destroyed, putting considerable strain on their livelihoods. During the land reform of 1950 to 1953, the local authorities distributed land among Cham, organized them into production units, and trained them to farm, while limiting their fishing-based economy to shallow sea areas. He also mentioned that, a few years later, the land that had been given to them was taken away again. Today, the Cham people in Sanya engage in a wide array of business activities, rather than farming. Some men work as rickshaw drivers, and many families own small restaurants, food stalls, or shops selling daily requisites. Many young Cham men and women are well educated and work as teachers or office clerks. Fishing has become more of an economic sideline than a main source of income. Yet I always find a number of Cham men on the coast busy with building new or improving old fishing boats, cleaning nets, and setting out on their night fishing trips.

Hainan has long been outside effective Chinese control, being inhabited by different groups such as the Cham, a maritime and mobile people who, through trade, connected China and Southeast Asia with the Arab world. Nowadays, China assigns these maritime people the allencompassing label of "Chinese fishers," while the Cham's long-standing presence at sea is silenced. In the case of Vietnam, the Cham heritage comes in handy for formulating nationalist 
claims of ancient differentiation from China without acknowledging the Cham maritime legacy on its own terms. In Lý Sơn, the Việt were the latest residents in the island's long history of settlement, and the Cham presence prior to their arrival in the seventeenth century still creates anxiety among Việt about their identity and rights over the land (Roszko 2016, 354). Southeast Asia historian Anthony Reid points out that the Cham remain "an embarrassment" to Vietnamese nationalism and "a reminder that borders have not always been where they came to rest in the colonial era, and that group identities were by no means fixed or immutable" $(1999,40)$. Thus, for Vietnam, more than for China, the Cham remain a source of deep territorial anxiety, which impels the state to project them as just an "ancient civilization," completely ignoring their seafaring legacy and interconnections in present-day national narratives of the SCS. While colonial maps of Cochinchina are often used by nationalists as the tool of modern and "objective" knowledge (Roszko 2015, 2016; Sasges 2016), those cartographic images that refer to "Champa" sit uncomfortably in the social memory of Vietnam and its society, which expanded southward through the pacification of the Cham territory into the Khmer realm.

\section{Việt, Cham, and Han beyond the Nation}

According to local narratives, the forefathers of Tanmen residents came mostly from the southern province of Fujian during the Song dynasty. When asked about their origins, Tanmen fishers claimed Han descent and distinguished themselves from the other fishing groups in the village, namely the Dan-jia (Tanka). Dan-jia is a term for boat dwellers who traditionally lived in floating villages in coastal parts of southern China and northern Vietnam. Although partly sedentarized by the Chinese government, the Dan-jia remain to this day a despised group at the bottom of the local social hierarchy. Even though the Dan-jia in Tanmen might have been there for two generations, they are considered migrant fishers in contrast to those who claim long-term settlement. As anthropologists Helen Siu and Liu Zhiwei (2006) argue in the case of the Pearl River Delta, it could be that the Tanmen's forefathers were of Dan-jia origin but, over time, through land reclamation, commerce, shipbuilding, and military service to the state, became sedentarized, simultaneously assuming new identities. By calling themselves Han, they distinguished themselves not only from later arrivals but also from the indigenous population in the area, namely the $\mathrm{Li}-$ the earliest-known inhabitants of Hainan, who historically made a living by fishing, hunting, and trading (Csete 2006; see also Siu and Zhiwei 2006, 290). 
A similar process occurred in Lý Sơn, where in the seventeenth century landless peasants and disadvantaged fishers arrived from the poverty-stricken northern coast of Vietnam (see Roszko 2016). However, neither Fujian nor Vietnamese migrants who came to Tanmen or Lý Son established themselves on empty soil; rather, they had to assimilate and interact with other communities who were already there. To this day, the older Cham generation in Hainan has retained close trading relations with the $\mathrm{Li}$, and both groups are fluent in each other's languages. However, young Cham people who rarely interact with the Li are losing their parents' or grandparents' multilingualism. Instead, most of these young people negotiate their ethnic, religious, and national identities via global Islam, regional Muslim links, and the dominant Han Chinese. ${ }^{12}$

Recently, scholars of China have been taking a revisionist look at the problem of representation and identity in China by unpacking the historical relationship of the prenineteenth-century category of "Han" vis-à-vis its contemporary conception (Gladney 2004; Mullaney et al. 2012). In his critical study of the idea of Han versus regional identities of Cantonese people within China, anthropologist Kevin Carrico describes the Han minzu (Han nationality) as "a massive melting pot, attempting to join peoples with vastly different local identities, customs, and dialects under a singular and one-dimensional label" $(2012,24)$. While the idea of the Han ren (Han person) existed for centuries as a culturists' label for the descendants of the Han dynasty, the notion of Han minzu as a homogeneous and singular ethnic identity is an invention that goes back to the nineteenth century, when the Qing empire became the present-day Chinese nation-state (Gladney 2004, 14).

Like the Han category in China, the idea of "Vietnameseness" enjoys a powerful and hegemonic position in Vietnam. I have written elsewhere that the idea of "Vietnameseness" dismisses regional, historical, and cultural differences and sidelines places such as Lý Sơn Island that do not represent the imagined culture of northern Vietnam (Roszko 2016, 352). Parallel to trends in scholarship on China, historians of Vietnam recently have pointed out different ways of acting Vietnamese that have existed across space and time (Taylor 1998, 2013; Li 1998, 2006; Tran and Reid 2006). Li contends that the Việt occupation of the land to the south in the seventeenth and eighteenth centuries was not a replacement of Cham culture and civilization with Vietnamese, but rather a "fruitful interaction ended by creating a new way of being Vietnamese" (Li 1998, 99). Lý Sơn villagers who embraced a rich array of ethnic and 
professional categories - as they intermingled with the Cham and engaged in sailing, pillaging, shipbuilding, trading, and fishing — are a living example of this dynamic process.

\section{Fishers, Seafarers, Traders, and Pirates}

At present, fluidity of ethnic and professional categories is rarely considered in the national seafaring narratives of Chinese and Vietnamese fishers. The people who are today called fishers often also functioned in the past as shipbuilders, sailors, traders, and pirates: spatial and temporal categories enacted in particular situations and contexts. These professional categories were always relational and situational rather than ontological. The label "pirate" was repeatedly attached to others, even though seafaring, fishery, trade, and piracy had always represented connected sea-oriented economies that did not recognize or respect political boundaries (Murray 1987; Warren 1981; Wheeler 2015).

In the last few years the Vietnamese party-state has become directly engaged in recovering and preserving local traditions and documents related to the Paracel (Hoàng $S a$ ) and Spratly (Truòng $S a$ ) flotillas, which, from the seventeenth to the nineteenth centuries, played an important role in exploiting the SCS under the Nguyễn lords and the Nguyễn dynasty, respectively (Roszko 2016). In most cases, a large number of skillful seamen were recruited from Lý Sơn Island, but the royal court in Huế also sought to involve the experienced Cham seafarers, who were rewarded with exemption from taxes (Bộ Ngoại Giao 2013, 10-11). This confirms Kenneth Hall's argument that the very same people could be engaged in different sea economies and sometimes turned to the service of the state $(2011,80)$. According to a preserved document of the Cham in Phu Quý Island (map 1), three vessels with Cham "fishermen," who were probably skillful sailors, shipbuilders, and traders, were launched to the Paracels and Spratlys at the command of King Minh Mạng (1791-1841) to mark the sea routes (Bộ Ngoại Giao 2013, $10-11)$.

In the seventeenth century, the Qing government (1644-1912) in China lifted its ban on maritime trade. The Dutch and other Europeans recognized lucrative trade opportunities and gradually replaced the Chinese in the trade sector in Southeast Asia (Schottenhammer 2012, 8485). Believing in the existence of a mythical long archipelago, Wan-li-Shi-tang, that blocked the direct route to Southeast Asia, Chinese merchants closely followed the coast of what today is Vietnam (Ptak 2006; see also Hayton 2015, 43). By contrast, European ships recklessly cut 
through the center of the SCS to find a direct route between Southeast Asian and Chinese ports. Crashing on the reefs, they incurred losses for their trading companies but provided others, such as the seafaring community of Lý Sơn or the Cham from Phu Quý, with opportunities to eke out a living. The recovery of gold, silver, swords, ivory, porcelain, cloth, wax, and many other goods from the Dutch, Spanish, Portuguese, or British wrecks was so profitable that Lý Sơn sailors were granted a royal concession to salvage the cargos. The spoils-often supplemented with catches of mother-of-pearl, snails, tortoises, and sea cucumbers - were handed over to the royal court in Huế (Lê Quý Đôn [1776] 2006, 155). Besides being exempted from taxes, the sailors received some monetary reward and were allowed to keep a large part of the harvested marine goods for their own profit (Lê Quý Đôn [1776] 2006, 155; see also Roszko 2016).

On the other side of the SCS, Hainanese seafarers ventured into the Paracels and Spratlys to procure sea cucumbers, tortoiseshells, shark fins, giant clams, and sea snails. The eighteenthcentury Vietnamese historian Lê Quý Đôn (Lê Quy Đôn [1776] 2006, 82b-85a, in Nguyễn 2008) noted the immediate proximity of Hainan Island to the Paracels and the friendly relations between the Paracel and Hainanese sailors who encountered each other in the archipelago. Lê Quý Đôn was not the only one who commented on the friendly interactions between sailors from Hainan and Vietnam. The presence of Hainanese sailors and lightly armed boats from Annam in the archipelago was also noted by a German missionary, who, in the mid-nineteenth century, traveled across East and Southeast Asia (Gutzlaff 1849). Around the same time, a Scottish hydrographer, James Horsburgh, recorded that some local seafarers from Hainan were undertaking fishing voyages lasting up to two months and stretching as far as 700 or 800 miles into the SCS $(1852,346)$. Collecting sea cucumbers, tortoiseshells, and other marine goods, they freely navigated their hardwood vessels between numerous reefs, shoals, and sandbanks of the Paracels and Spratlys in the SCS. While these rocks and reefs were a deadly hazard for Europeans, for Cham, Việt, and Hainanese seafarers they were part of their livelihood, which was based on maritime knowledge, navigation skills, and trade. During my conversation with Tanmen fishers, many recalled stories of their forefathers' voyages to the two archipelagos. It was not rare to take a buffalo along in order to graze it on the grassier islets of the Paracels and spend more than a month there fishing for turtles and sea snails and waiting for the collected sea cucumbers to dry in the sun. 
The precolonial and colonial sources are repeatedly cited as proof of Vietnamese sovereignty, but when read in their entirety they demonstrate instead that for neo-Confucian Vietnam and China, sovereignty was about people, not territories (Sasges 2016; Hill 1991). Therefore, rather than discussing whether the colonial sources confirm or deny Vietnamese or Chinese sovereignty over the disputed territories, I want to draw attention to the detail, in Gutzlaff's passage, that fishers from both Annam (present-day Central Vietnam) and Hainan were historically present in the Paracels and Spratlys. The German missionary described this as follows:

From time immemorial, junks in large number from Haenan [sic], have annually visited all these shoals and proceeded in their excursions as far as the coast of Borneo. Though more than ten per cent. are annually wrecked, the quantity of fish taken is so great as to ensure all loss, and still leave a very good profit. The Annam government, perceiving the advantages which it might derive if a toll were raised, keeps revenue cutters and a small garrison on the spot to collect the duty on all visitors, and to ensure protection to its own fishermen. A considerable intercourse has thus gradually been established, and promises to grow in importance on account of the abundance of fish which come to these banks to spawn. Some islets bear a [sic] stunted vegetation, but fresh water is wanting; and those sailors who neglect to take with them a good supply are often put to great straits (Gutzlaff 1849, 93).

The elderly residents of Tanmen and Lý Sơn whom I spoke with considered the two archipelagos to be their traditional fishing grounds and underlined their own cosmopolitan status as traders. Lý Sơn people explained that their ancestors ventured into the Paracels and Spratlys before the royal court in Huế found out about their profitable salvage of the wrecked ships and, ultimately, ordered them to formalize their activities as the Paracel and Spratly flotillas. Referring to the SCS dispute, they also said that - whether or not the Vietnamese government would provide financial or military support for their fishing fleets - the islanders were determined to continue their operations in those areas, because this was how they had always earned their livelihood (Roszko 2016, 364).

\section{Fishing and Pillaging}

Historian Robert Antony (2014) provides a fascinating case study of a little-known pirate, Yang Yandi (V. Dương Ngan Địch), who in the seventeenth century operated in the SinoVietnamese water frontier of the Gulf of Tonkin and was considered a rebel by the Qing court, 
but a hero by the Nguyễn lords in southern Vietnam. Roberts observed that, "given the hectic, uncertain conditions, sharp distinctions between trade, smuggling and piracy were always blurry" $(2014,8)$. Moreover, switching loyalty from Việt to Chinese or vice versa was a common practice (Tagliacozzo 2009; Sellers 1983). Periodically, organized piracy, plundering, or smuggling - which could sometimes be turned into formalized trade-fit the description of various profitable activities undertaken in the past by Lý Sơn and Hainan seafarers. Historically, these activities constituted an important part of local life and economy and supplemented fishing. For Lý Sơn sailors, the salvaged cargos from wrecked European merchant ships offered a good profit, while for Hainan residents, the abundance of rich shipments passing the east coast of Hainan represented easy prey and a boost to their livelihood. Already during the Song dynasty (960-1279), many foreign merchants were captured and enslaved by powerful Hainanese chieftains of various hill tribes (Chiu 2004, 230). But it was the maritime trade proscription by the Ming government (1368-1644) that intensified piracy, which-with the interruption of private foreign trade - became endemic on Hainan (Schottenhammer 2012; Calanca 2001). The Qing court restored the maritime trade, but the problem of piracy persisted in spite of the Qing's aggressive policy of interdiction and punishment and — when that failed - pacification.

A report of the expedition to Hainan by British consul Robert Swinhoe dated June 13, 1868, made clear that some of the small harbors formed by reefs and lagoons on the east and southwest side of Hainan provided excellent hiding places for pirate junks and their crews, who seasonally also engaged in fishing. Known in British logbooks as Guangdong or Pulo Canton, Lý Son Island was also considered a dangerous and inaccessible place for ships to anchor due to the coral reef and rocks surrounding its coast (White 1824,75), and it was thus a perfect location for those elements labeled "pirates" by Europeans. Europeans considered Lý Sơn Island a key marker on their way to Guangdong, before they used the sea-lane through the Macclesfield Bank. They needed to have the island on their right side; otherwise, they could run dangerously aground at the Paracels. ${ }^{13}$ For example, on June 27, 1839, a French merchant ship was stranded and submerged in the Paracels. The eleven crew members reached the Đà Nẵng port on small boats and called out for help. The port authorities sent the Hoàng Sa navy to bring the rest of the crew to safety, and the case was reported to King Minh Mạng (Bộ Ngoại Giao 2013, 80). 


\section{Shipbuilding and Trade}

Historically, Lý Sơn and Tanmen were sites of local shipbuilding, which required considerable maritime knowledge and seafaring skills. The basket boat-mocked by one of the Tanmen villagers above-was highly popular up to the nineteenth century in southern Vietnam, but its style was borrowed from the Cham (Li 1998, 112; Pham 2013). The Cham themselves were influenced by Malays and Arabs with whom they traded in the region. The Cham boats I have seen on the Sanya shore were often described by ethnic Chinese as "primitive," because they were built from light material such as planks, bamboo, and Styrofoam. However, I would argue that they reflect long-term experience on the sea and genuine skill in blending various technologies. The bamboo planks in the Cham boats were sewn together with rope without using nails, a shipbuilding technique typical of traditional Arab dhows used in the Indian Ocean (see Sheriff 2010). ${ }^{14}$ Historian and maritime archeologist Charlotte Pham (2013) points out that Chinese boatbuilding was influenced by Southeast Asian ships, but technological evolutions_-as the examples above show-were complex and multidimensional. This suggests that fishers in Hainan and Vietnam were not a homogeneous group and that their language, customs, and fishing junks differed from group to group. Commenting on one of the fishing groups in southwest Hainan in 1868, Swinhoe wrote that "the fishermen were the most barbarous we have seen on this coast, many of them perfectly naked. Their boats were constructed very like the Japanese boats at Nagasaki" (1868, 13).

Regardless of exactly who those fishers were, boatbuilding was a "repository of cultural and technological exchanges but also a cradle of and source of interconnectedness" (Pham 2013, 162). Procuring the timber for constructing their junks required Lý Sơn and Tanmen residents to undertake sea voyages along Vietnam's coast and interact with other communities. Historically, it was common practice for Hainan sojourning seafarers to take local wives in Vietnam, Indonesia, or Thailand to facilitate trade and communication. Using their local networks, these seafarers cut timber in Champa (known as Annam, or present-day Central Vietnam) and Cambodia and then bought an additional quantity in Bangkok, where they would spend up to two months building junks. These junks, loaded with rice, would return to Hainan or Canton, where they would be sold for good profit together with their cargos (Gutzlaff 1834, 82-83). Since the rice grown was insufficient to meet the needs of the Tanmen population, marine goods, livestock, raw sugar, betel nut, rattan, incense timber, and medical plants were also traded to 
Southeast Asian countries, including Cochin-China, Singapore, and Siam (see Michalk 1985, 121; Csete 2006, 229), to provide income for buying rice.

As in the case of Tanmen, Lý Sơn people continued to capitalize on their seafaring capacity when the flotillas ceased their naval activities in the Paracels and Spratlys. Following the cold winter monsoon, they sailed to the south, where they traded salt and local products such as fish sauce, peanut oil, and fishing nets. Waiting for the southern summer monsoon, they would offer themselves as seasonal labor to rich French and Chinese people. The income they earned was used to purchase rice that was shipped back to Lý Sơn (Roszko 2016; see also Li 2004). En route home, Lý Sơn sailors would take on board Cham traders of medicinal plants, which were in great demand on the island.

Reflecting on the mobility and skills of Lý Sơn or Tanmen people, we could say that the occupational roles they embraced did not rest exclusively on fishing and shipbuilding; seafaring and trade came in handy at all times. The blurred lines and fluidity between professions and ethnicity problematize conceptualizations of a monolithic Chinese or Vietnamese nation and culture (Evans 2002). Probing into the past requires giving up "the distorting lens of the nation" (Evans 2002, 159) and bringing to light many pasts that were driven by both ecology and people (Taylor and Whitmore 1995).

\section{Conclusion}

My aim in this article is not to legitimize or delegitimize the territorial claims of Vietnam and China to the SCS but to engage with national and territorial cartographic anxieties from a different angle. I built my ethnography of fisheries in the SCS beyond the nation-state frame on maritime Asia historian Charles Wheeler's idea (2006) of connecting the usually separated histories of the Cham, Vietnamese, and Chinese. In both Vietnam and China, the seafaring legacy of the Cham and their trading system in the SCS are rarely mentioned in relation to fishers, who nowadays figure so prominently in mediated state discourses. The passionate narrative given by the Cham elder in Sanya reveals that probing into Lý Sơn and Tanmen fishers' experience at sea requires taking account of the cosmopolitan histories and voices of various Cham people who were present through centuries within the same space and time. Lý Sơn and Hainan fishers did not exist in a social vacuum, nor were their communities static and homogeneous; rather, they were, in Tagliacozzo's words, "part of a larger, maritime nexus, linked by religion, trade and a 
cosmopolitan outlook" (2009 100; see also Wheeler 2006; Roszko 2016). These historical patterns in the form of mobility and commercial networks persisted among different coastal communities, though the latter-day connection of fisheries to sovereignty and state security is a strategy of these marginalized societies for claiming economic benefits within the state system (see Siu and Zhiwei 2006). In the case of Tanmen and Lý Son, I argue that the Chinese and Vietnamese fishers' territorial anxieties around the issue of who had the maritime skills and knowledge to go to the Paracels and Spratlys are also a facet of broader cartographic and national anxieties over who has legitimate rights to the sea and whose seafaring legacy deserves to be mapped and remembered. More importantly, territorial anxieties show uneven and asymmetric relationships between Vietnam and China and different levels of interaction, through which state and non-state actors seek to pursue their ideologically and economically motivated desires and goals.

Rather than being proof of hostile attitudes or eternal friendship, the contradictory narratives and reluctance of Chinese and Vietnamese to openly acknowledge each other's longstanding presence and interactions at sea touch on the problem of how fishers are politically and economically implicated in the current geopolitical conflict in the SCS. In the process, the monolithic categories of Việt and Han come to mark the newly rediscovered national territory of remote rocks, shoals, sandbanks, and reefs - maritime frontiers of Vietnam and China that did not exist in the same way before the invention of the Global Positioning System (GPS). Ever since then, it has been possible for states to claim remote stretches of the sea and their maritime features. Along with the official rhetoric concerning the development of marine resources through the modernization of fishing fleets, the putative historical presence of fishers and their customary practices in the SCS are increasingly used by China and Vietnam as legal arguments in contemporary territorial claims, while ignoring the centuries-old presence of other seafaring communities such as the Cham and their connections with the SCS.

This article problematizes the all-encompassing categories of Chinese or Vietnamese fishers and questions those SCS narratives that separate histories of China, Vietnam, and Cham. Offering alternative and more inclusive narratives of Tanmen and Lý Sơn, I have shown that the ethnic and professional categories have always been embodied, relational, and temporal, as the vast sea spaces divided and connected different coastal communities across the SCS. Navigating the SCS was not just a matter of contacting new people but more often an issue of renewing old 
ties and networks (Tagliacozzo 2009, 114). In those watery realms, Việt, Cham, and Chinese histories intermingled, making ethnic and occupational labels fluid, depending on geographical and historical contexts. Today, to deal with the boundlessness of the sea, the professional label of "fisherman" is combined with the national categories of "Vietnamese" or "Chinese" to enforce present-day maritime enclosures and project them into the past despite the common historical, cultural, and ethnic flows that always existed in the SCS. Paraphrasing South Asia historian Sunil Amrith, who rightly observes that "oceanic history is itself a kind of cartography" (2013, 285), I argue that by foregrounding the SCS's fishers-linked by seafaring skills, trade, and voyages - we can see beyond the imposed cartographic order and territorial anxieties of the modern nation-state to a more inclusive world, in which Cham history does not end where Lý Sơn and Hainan histories begin. In this world, fishing - next to trade and seafaring - has no definable national borders.

Edyta Roszko is a postdoc in the department of Cross-Cultural and Regional Studies at the University of Copenhagen. Research for this article was funded by the People Programme (Marie Curie Actions) of the People's Union's Seventh Framework Programme (FP7/2007-2013) under REA grant agreement no. PIEF-GA-2012-326795 and by the Danish Council for Independent Research in Culture and Humanities under agreement no. 0602-02917B/FKK. The author's deepest thanks go to Franck Billé for his invitation to contribute to this special issue and for his valuable comments. She is also grateful to Keila Diehl and three anonymous reviewers for Cross-Currents for their clarifying comments and suggestions.

\section{Notes}

1 The Nine-Dash Line refers to the demarcation line used by China to claim its sovereignty over sea features within the lines and its right to marine and submarine resources. See Marina Tsirbas, "What Does the Nine-Dash Line Actually Mean?," The Diplomat, June 2, 2016, http://thediplomat.com/2016/06/what-does-the-nine-dash-line-actually-mean/, accessed November 29, 2016.

2 See "PCA Press Release: The South China Sea Arbitration" ("The Republic of the Philippines v. the People's Republic of China"), July 12, 2016. Available at Permanent Court of Arbitration website, https://pca-cpa.org/wp-content/uploads/sites/175/2016/07 /PH-CN-20160712-Press-Release-No-11-English.pdf, accessed July 12, 2016.

3 See, for example, James Lillywhite, "South China Sea Dispute: Anti-Beijing Protesters in Vietnam Mark Battle of the Paracel Islands Anniversary," International Business Times, January 19, 2016, http://www.ibtimes.co.uk/south-china-sea-dispute-anti-beijing -protesters-vietnam-mark-battle-paracel-islands-anniversary-1538765, accessed May 13, 2016. 
4 I analyzed maritime territorialization, sovereignty, and territoriality in the context of the SCS disputes in Roszko (2015).

5 These are slogans I saw on propaganda posters during my field research in Tanmen and Lý Sơn in 2014 and 2015.

6 Hainan Island is located about 170 nautical miles $(281 \mathrm{~km})$ from the Paracels. The total population of Tanmen is about 30,000 people, 9,000 of whom are engaged in fishing. The Cham population in Sanya is estimated at around 5,000 people (Thurgood, Thurgood, and Li 2006, 12).

$7 \quad$ For the Buginese connection with the South China Sea, see Warren (1981).

8 See, for example, "Our Geng Lu Bu Is on CCTV1," July 14, 2016, Foreign Affairs Office of Hainan Province website, http://enfaohn.hainan.gov.cn/swsqwywb/wsqwbgsWNWQ /201607/t20160714_2063329.htm, accessed July 20, 2016.

9 Fishers in China get updates about new fishing laws and regulations through the Fishery Law Enforcement Command, and in Vietnam through the Fisheries and Aquaculture Department.

10 The so-called Haiyang Shiyou 981 incident refers to the crises in Sino-Vietnamese relations caused by China's installation of an oil rig in the area claimed by Vietnam as its EEZ.

11 Lý Sơn Island was also an important part of a network of wells providing freshwater to Cham sailors but also to Arab and other foreign ships (Hardy 2009, 111).

12 The integration of Cham into Chinese society and their various strategies to navigate between different ethnic lines deserve a separate analysis beyond the scope of this article. For Vietnam, see Nakamura (2000) and Taylor (2007).

13 I am grateful to Francois-Xavier Bonnet (personal communication, March 21, 2016) for this information.

14 I am grateful to Engseng Ho (personal communication, June 20, 2016) for pointing out the connection of the Cham boats with traditional dhows in the Indian Ocean.

\section{References}

Amrith, Sunil S. 2013. Crossing the Bay of Bengal: The Furies of Nature and the Fortunes of Migrants. Cambridge, MA: Harvard University Press.

Antony, Robert J. 2014. "'Righteous Yang': Pirate, Rebel, and Hero on the Sino-Vietnamese Water Frontier, 1644-1684." Cross-Currents: East Asian History and Culture Review 11:4-30. Available at https://cross-currents.berkeley.edu/e-journal/issue-11/antony, accessed May 10, 2016.

Bộ Ngoại Giao - Uỷ Ban Biên Giới Quốc Gia [Ministry of Foreign Affairs - National Border Committee]. 2013. Tuyển tập các châu bàn Triệu Nguyễn về thưc thi chủ quyền của Việt Nam trên hải quần đảo Hoàng Sa và Trường Sa [Collection of official documents of the Nguyen dynasty on the exercise of sovereignty of Vietnam over the Paracel and Spratly archipelagoes]. Edited by Lê Quý Quỳnh, Đình Ngọc Linh, and Phạm Văn Thắm. Hà Nôi: Nhà Xuất bản Tri thức.

Bonnet, François-Xavier. 2012. "Geopolitics of Scarborough Shoal.” Irasec's Discussion Paper $14: 1-42$. 
Braudel, Fernand. 1995. The Mediterranean and the Mediterranean World in the Age of Philip II. Berkeley: University of California Press.

Broers, Laurence, and Gerard Toal. 2013. "Cartographic Exhibitionism? Visualizing the Territory of Armenia and Karabakh." Problems of Post-Communism 60 (3): 16-35.

Buszynski, Leszek, and Christopher B. Roberts. 2015. The South China Sea Maritime Dispute: Political, Legal and Regional Perspectives. New York: Routledge.

Calanca, Paola. 2001. "Aspects spécifiques de la piraterie à Hainan sous les Ming et au début des Qing" [Scientific aspects of piracy in Hainan under the Ming and at the beginning of the Qing]. In Hainan: De la Chine à l'Asie du Sud-Est [Hainan: From China to Southeast Asia], edited by Claudine Salmon and Roderich Ptak, 111-136. Wiesbaden: Harrassowitz Verlag.

Callahan, William A. 2009. "The Cartography of National Humiliation and the Emergence of China's Geobody." Public Culture 21 (1): 141-173.

Carrico, Kevin. 2012. "Recentering China: The Cantonese in and beyond Han." In Critical Han Studies: The History, Representation and Identity of China's Majority, edited by Thomas S. Mullaney, James Leibold, Stéphane Gros, and Eric Vanden Bussche, 23-44. Berkeley: University of California Press.

Chan, Yuk Wah. 2013. Vietnamese-Chinese Relationships at the Borderlands: Trade, Tourism and Cultural Politics. London: Routledge.

Chaudhuri, K. N. 1985. Trade and Civilisation in the Indian Ocean: An Economic History from the Rise of Islam to 1750. Cambridge: Cambridge University Press.

Chemillier-Gendreau, M. 2000. Sovereignty over the Paracel and Spratly Islands. The Hague: Kluwer Law International.

Chiu, James. 2004. "Ports, Merchants, Chieftains and Eunuchs: Reading Maritime Commerce of Early Guangdong." In Guangdong: Archeology and Early Texts, edited by Shing Müller, Thomas O. Höllman, and Putao Gui, 217-239. Wiesbaden: Harrassowitz Verlag.

Csete, Anne. 2006. "Ethnicity, Conflict, and the State in the Early to Mid-Qing: The Hainan Highlands, 1644-1800." In Empire at the Margins: Culture, Ethnicity and Frontier in Early Modern China, edited by Pamela Kyle Crossley, Helen F. Siu, and Donald S. Sutton, 229-252. Berkeley: University of California Press.

Duara, Prasenjit. 1995. Rescuing History from the Nation: Questioning Narratives of Modern China. Chicago, IL: The University of Chicago Press.

Elden, Stuart. 2009. Terror and Territory: The Spatial Extent of Sovereignty. Minneapolis: University of Minnesota Press.

- 2013. The Birth of Territory. Chicago, IL: University of Chicago Press.

Evans, Grant. 2002. "Between the Global and the Local There Are Regions, Culture Areas, and National States: A Review Article." Journal of Southeast Asian Studies 33 (1): 147-162.

Gladney, Dru C. 2004. Dislocating China: Reflections on Muslims, Minorities and Other Subaltern Subjects. London: Hurst and Company.

Gutzlaff, Charles. 1834. Journal of three voyages along the coast of China, in 1831, 1832, \& 1833, with notices of Siam, Corea and the Loo-Choo Islands. London: Westley and Davis. Available at https://archive.org/details/journalthreevoy01elligoog, accessed November 29, 2016.

Gutzlaff, [first name unknown]. 1849. "Geography of the Cochin-Chinese Empire." The Journal of the Royal Geographical Society of London 19:85-143. 
Hall, Kenneth R. 2011. A History of Early Southeast Asia: Maritime Trade and Societal Development, 100-1500. Lanham, MD: Rowman and Littlefield.

Hamashita, Takeshi. 2008. China, East Asia and the Global Economy: Regional and Historical Perspectives, edited by Linda Grove and Mark Selden. London: Routledge.

Hardy, Andrew. 2009. "Eaglewood and the Economic History of Champa and Central Vietnam." In Champa and the Archeology of Mỹ Son (Vietnam), edited by Andrew Hardy, Mauro Cucarzi, and Patrizia Zolese, 107-126. Singapore: NUS Press.

Hayton, Bill. 2014. The South China Sea: The Struggle for Power in Asia. New Haven, CT: Yale University Press.

Hill, R. D. 1991. "Fishing in Troubled Waters: Some Thoughts on Territorial Claims in the South China Sea." In Fishing in Troubled Waters: Proceedings of An Academic Conference on Territorial Claims in the South China Sea, edited by R. D. Hill, G. O. Norman, and E. V. Roberts. Centre of Asian Studies Occasional Papers and Monographs 97. Hong Kong: University of Hong Kong.

Hill, R. D., Norman G. Owen, and E. V. Roberts, eds. 1991. Fishing in Troubled Waters: Proceedings of an Academic Conference on Territorial Claims in the South China Sea. Centre of Asian Studies Occasional Papers and Monographs 97. Hong Kong: University of Hong Kong.

Ho, Engseng. 2006. Graves of Tarim: Geneaology and Mobility across the Indian Ocean. Berkeley: University of California Press.

Horsburgh, James. 1852. The India Directory or, Directions for Sailing to and from the East Indies, China, Australia and the Interjacent Ports of Africa and South America. 6th edition, vol. 2. London: WM. H. Allen and Co.

Krishna, Sankaran. 1994. "Cartographic Anxiety: Mapping the Body Politic in India." Alternatives: Global, Local, Political 19 (4): 507-521.

Lại Văn Tới. 2015. "Sovereignty of Vietnam over the East Sea from Archeological Documents." Vietnam Social Science 1 (165): 53-70. Available at http://vjol.info.vn/index.php/VSS /article/view/20086/0, accessed July 15, 2016.

Lê Quý Đôn. (1776) 2006. Phủ Biên Tạp Lục [A compilation of the miscellaneous records when the southern border was pacified]. Vol. 1. Hà Nôi: Nhà xuầt bản văn hóa thông tin.

Li, Tana. 1998. Nguyễn Cochinchina: Southern Vietnam in the Seventeenth and Eighteenth Centuries. Ithaca, NY: Cornell University Press.

- 2004. "Rice from Saigon: The Singapore Chinese and the Saigon Trade of the Nineteenth Century." In Guandong: Archeology and Early Texts, edited by Shing Müller, Thomas O. Höllman, and Putao Gui, 261-270. Wiesbaden: Harrassowitz Verlag. . 2006. "A View from the Sea: Perspectives on the Northern and Central Vietnamese Coast." Journal of Southeast Asian Studies, 37 (1): 83-102.

Michalk, D. L. 1985. "Hainan Island: A Brief Historical Sketch.” Journal of the Hong Kong Branch of the Royal Asiatic Society 26:115-143.

Mullaney, Thomas S. 2012. "Critical Han Studies: Introduction and Prolegomenon.” In Critical Han Studies: The History, Representation and Identity of China's Majority, edited by Thomas S. Mullaney, James Leibold, Stéphane Gros, and Eric Vanden Bussche, 1-22. Berkeley: University of California Press. 
Mullaney, Thomas S., James Leibold, Stéphane Gros, and Eric Vanden Bussche, eds. 2012. Critical Han Studies: The History, Representation and Identity of China's Majority. Berkeley: University of California Press.

Murray, Dian H. 1987. Pirates of the South China Coast, 1790-1810. Stanford, CA: Stanford University Press.

Nakamura, R. 2000. "The Coming of Islam to Champa." Journal of the Malaysian Branch of the Royal Asiatic Society 73 (1): 55-66.

Nguyễn, Q. Thắng. 2008. Hoàng Sa Trương Sa Lãnh thổ Việt Nam: Nhìn tù Công pháp Quốc tế [Vietnam's territory of the Paracels and Spratlys: The international legal]. Hà Nôi: Nhà Xuất bản Tri thức.

Painter, Joe. 2008. "Cartographic Anxiety and the Search for Regionality." Environment and Planning A 40 (2): 342-361.

Pham, Charlotte. 2013. "The Vietnamese Coastline: A Maritime Cultural Landscape." In The Sea, Identity and History: From the Bay of Bengal to the South China Sea, edited by S. Chandra and H. P. Ray, 137-167. Delhi: Society for Indian Ocean Studies.

Ptak, Roderich. 2006. "The Sino-European Map (Shanhai yudi quantu) in the Encyclopedia Sancai Tuhui." In The Perception of Maritime Space in Traditional Chinese Sources, edited by Angela Schottenhammer and Roderich Ptak, 191-207. Wiesbaden: Harrassowitz Verlag.

Reid, Anthony. 1999. Charting the Shape of Early Modern Southeast Asia. Bangkok: Silkworm Books.

Roszko, Edyta. 2015. "Maritime Territorialisation as Performance of Sovereignty and Nationhood in the South China Sea." Nations and Nationalism 21 (2): 230-249. . 2016. "Geographies of Connection and Disconnection: Narratives of Seafaring in Lý Sơn." In Connected and Disconnected in Vietnam: Remaking Social Relationships in a Post-Socialist Nation, edited by Philip Taylor, 347-377. Canberra: Australian National University Press.

Sasges, Gerard. 2016. "Absent Maps, Marine Science, and the Reimagination of the South China Sea, 1922-1939." The Journal of Asian Studies 75 (1): 157-180.

Schottenhammer, Angela. 2012. "The 'China Seas' in World History: A General Outline of the Role of Chinese and East Asian Maritime Space from Its Origin to c. 1800." Journal of Marine and Island Culture 1:63-89.

Sellers, Nicholas. 1983. The Princes of Hà-Tiên (1682-1867). Etudes Orientales 11. Brussels: Thanh Long.

Sheriff, Abdhul. 2010. Dhow Cultures of the Indian Ocean: Cosmopolitanism, Commerce and Islam. London: Hurst and Company and the Zanzibar Indian Ocean Research Institute.

Sheriff, Abdhul, and Engseng Ho, eds. 2014. The Indian Ocean: Oceanic Connections and Creation of New Societies. London: Hurst and Company.

Siu, Helen F., and Zhiwei Liu. 2006. "Lineage, Market, Pirate and Dan: Ethnicity in the Sands of South China." In Empire at the Margins: Culture, Frontier and Ethnicity in Early Modern China, edited by Pamela Crossley and Donald Sutton, 285-310. Berkeley: University of California Press.

Siu, Helen F., Eric Tagliacozzo, and Peter C. Perdue. 2015. "Introduction: Spatial Assemblages." In Asia Inside Out: Connected Places, edited by Eric Tagliacozzo, Helen F. Siu, and Peter C. Perdue, 1-30. Cambridge, MA: Harvard University Press. 
Sutherland, Claire. 2014. "Borders of Belonging: The UK Border Agency Museum as a NationBuilding Site." In Challenging History in the Museum: International Perspectives, edited by Jenny Kidd, Sam Cairns, Alex Drago, and Amy Ryall, 175-186. Surrey: Ashgate.

Swinhoe, Robert. 1868. Visit to Island of Hainan. In H.M.S. “Algerine.” Date: June 13, 1868. Reference FO 881/1630. The National Archives, London.

Tagliacozzo, Eric. 2009. "Navigating Communities: Race, Place, and Travel in the History of Maritime Southeast Asia." Asian Ethnicity 10 (2): 97-120.

Tagliacozzo, Eric, and Wen-Chin Chang, eds. 2011. Chinese Circulations: Capital, Commodities and Networks in Southeast Asia. Durham, NC: Duke University Press.

Tagliacozzo, Eric, Helen F. Siu, and Peter C. Perdue, eds. 2015. Asia Inside Out: Connected Places. Cambridge, MA: Harvard University Press.

Taylor, Keith W. 1998. "Surface Orientation in Vietnam: Beyond Histories of Nation and Region." The Journal of Asian Studies 57 (4): 949-978. . 2013. A History of Vietnamese. Cambridge: Cambridge University Press.

Taylor, Keith W., and John K. Whitmore, eds. 1995. Essays into Vietnamese Pasts. Ithaca, NY: Cornell University Press, Cornell Southeast Asia Program.

Taylor, Philip. 2007. Cham Muslims of the Mekong Delta. Singapore: National University of Singapore Press.

Thurgood, Graham. 1999. From Ancient Cham to Modern Dialects: Two Thousand Years of Language Contact and Change. Honolulu: University of Hawai'i Press.

Thurgood, Graham, Ela Thurgood, and Li Fengxiang. 2006. A Grammatical Sketch of Hainan Cham, Contact, and Phonology. Pacific Linguistics [PL] 643. Berlin: De Gruyter Mounton.

Tønnensson, S. 2006. "The South China Sea in the Age of European Decline." Modern Asian Studies 40 (1): 1-57.

Tran, Nhung Tuyet, and Anthony J. S. Reid, eds. 2006. Việt Nam Borderless Histories. Madison: University of Wisconsin Press.

Warren, James F. 1981. The Sulu Zone, 1768-1898. Singapore: Singapore University Press.

Wheeler, Charles. 2006. "One Region, Two Histories: Cham Precedents in the History of Hoi An Region." In Việt Nam: Borderless Histories, edited by Nhunh Tuyet Tran and Anthony J. S. Reid, 163-193. Madison: University of Wisconsin Press. . 2015. "Placing the 'Chinese Pirates' of the Gulf of Tonking at the End of the Eighteenth Century." In Asia Inside Out: Connected Places, edited by Eric Tagliacozzo, Helen F. Siu, and Peter C. Perdue, 30-63. Cambridge, MA: Harvard University Press.

White, John. 1824. A Voyage to Cochin China. London: Longman, Hurst, Rees, Orme, Brown, and Green.

Winichakul, Thongchai. 1994. Siam Mapped: A History of the Geo-Body of the Nation. Honolulu: University of Hawai'i Press.

Wirth, Christian. 2016. "Securing the Seas, Securing the State: Hope, Danger and Politics of Order in the Asia-Pacific." Political Geography 53:76-85.

Zhang, Hongzhou. 2016. "Chinese Fishermen in Disputed Waters: Not Quite a 'People's War."' Marine Policy 68:65-73. 